\title{
PENGEMBANGAN INSTRUMEN ASESMEN MATA KULIAH PRAKTIK TATA BUSANA PADA PROGRAM STUDI PENDIDIKAN TATA BUSANA
}

\author{
I Gede Sudirtha ${ }^{1}$, Putu Agus Mayuni ${ }^{2}$, I Dewa Ayu Made Budhyani ${ }^{3}$ \\ 1,2,3 Jurusan Pendidikan Kesejahteraan Keluarga \\ Universitas Pendidikan Ganesha \\ Singaraja, Indonesia
}

e-mail: sudirtha_gede@yahoo.com

\begin{abstract}
Abstrak
Penelitian ini bertujuan untuk : 1) Merancang instrumen asesmen kinerja untuk Mata Praktek Busana di Program Studi Pendidikan Tata Busana dengan langkahlangkah validitas dan reliabilitas yang tepat dalam pengembangan perangkat instrumen asesmen sebagai asesmen proses dan produk. Penelitian ini merupakan penelitian pengembangan (research and development) dengan beberapa tahapan. Subjek penelitian ini adalah mahasiswa Program Studi Pendidikan Tata Busana, dengan fokus penelitian adalah pengembangan perangkat ssesmen Mata Kuliah Praktek Tata Busana. Adapun aspek-aspek penelitian, sumber data, teknik dan instrumen/alat pengumpul data, dan validasi dan reliabilitas instrumen yang digunakan dalam penelitian dilakukan dengan teknik wawancara, observasi, dan pencatatan dokumen. Data penelitian ini berupa data kuantitatif, dan analisis dilakukan dengan analisis statistik terkait uji empirik (validasi instrumen) yang meliputi uji content validity dan dan validitas internal. Analisis deskriptif dilakukan untuk memberi makna terhadap deskripsi data penelitian. Hasil penelitian menunjukkan : 1) rancangan perangkat instrumen Mata Kuliah Praktek Tata Busana yang dikembangkan melalui tahap analisis kebutuhan instrumen yang dilakukan melalui kajian pustaka dan kajian terhadap kompetensi Mata Kuliah Praktek Tata Busana dengan melibatkan tim peneliti, praktisi, pakar evaluasi dan pengampu mata kuliah. Kajian ini menghasilkan beberapa aspek penting yang perlu diungkap dalam penilaian praktek tata busana yang diturunkan dari beberapa standar kompetensi dan kompetensi dasar, serta indikator pencapaian hasil belajar yang dikehendaki dalam Mata Kuliah Praktek Tata Busana, dengan mengurutkan kemampuan-kemampuan berdasarkan urutan pengamatan. Adapun beberapa aspek kemampuan/ unjuk kerja tersebut diuraikan menjadi beberapa tahapan yaitu : (1) unjuk kerja menganalisa desain, (2) unjuk kerja membuat pola dan pecah model, (3) unjuk kerja penempatan pola pada bahan dan memotong bahan, (4) unjuk kerja menjahit/menggabungkan bagianbagian busana, dan (5) unjuk kerja finishing, mendisplay dan pengemasan busana. Selanjutnya disusun kisi-kisi instrumen dan perangkat instrumen tahapan kinerja dan satu tahapan penilaian dengan menggunakan asesemen produk. Untuk mengetahui validitas konstruk dilakukan dengan analisis faktor. Instrumen diuji cobakan pada 17 orang sampel. Item/butir instrumen yang mempunyai korelasi positif dengan kriterium (skor total) dan korelasi yang tinggi, menunjukkan bahwa item tersebut mempunyai validitas yang tinggi. Syarat minimum adalah $r_{\text {hitung }}=0,30$.
\end{abstract}


Dari 40 butir tes yang diuji coba menunjukkan validitas yang dapat di andalkan $\left(r_{\text {hitung }}>0.5\right)$. Reliabilitas instrumen menggunakan kaidah Cronbach alpha, dengan mencari koefisien reliabilitas gabungan. Indeks reliabilitasnya dihitung dengan koefisien alpha dari Cronbach dan kriteria instrumen yang reliabel ditunjukkan oleh koefisien reliabilitas $\geq 0,5$. Hasil uji coba menunjukkan dari 5 instrumen yang dikembangkan memiliki tingkat reliabilitas yang dapat diandalkan ( $r$ hitung $>0.6$ ). 2) diperlukan suatu prosedur penggunaan asesemen kinerja yang bersifat praktis, efisien dan mudah dipahami dalam pelaksanan asesemen. Lebih lanjut dalam pengembangan asesemen kinerja sangat dibutuhkan kajian yang mendalam tentang bagaimana mengembangkan prosedur asesemen kinerja yang praktis dan efisien.

Kata kunci : pengembangan, instrumen asesmen, praktek tata busana

\begin{abstract}
This study aims to : 1) Develop a performance assessment instrument for in dressmaking Education Program by appropriate validity and reliability procedure in the development of the assessment instrument as the assessment process and products. 2) identify and assess the procedures of assessement usage. This research is a development research (R\&D). The research focuses on the development of assessment instrument for Makeup Training Subject. The aspects of research, data sources, techniques and instruments/data collection instrument, and validation and reliability of the instrument used in the study conducted by interview, observation, and literature and documents. The data of this study is quantitative data which was statistically analyzed due to relevant empirical testing (validation of instruments) that includes testing and content validity and internal validity. Descriptive analyzes were undertaken to describe the research data. The results showed: 1) The design of the instrument practice clothing subject are developed through the needs analysis. It is done through literature review and study of the course competencies by engaging a team of researchers. This study resulted in the instrument guidelines and assessment instrument completed with its scoring rubrics. However, other aspects of the capability/ performance is broken down into several stages: (1) analyze design performance, (2) performance patterns and rupture model, (3) the performance of the placement of the pattern on the material and cut material, (4) show working sewing / fashion combine parts, and (5) performance finishing, displaying and packing clothing. The instrument comprising: a step of validity assessment is done through the stages : experts judgment, empirical tests to prove the validity and reliability of the instruments assessment. All the performance test instrument developed is valid $\left(r_{x y}>0.30\right)$ and reliable $\left(r_{x x^{\prime}}>0.60\right)$. Assessment instruments besides the assessment process and results of this study have had a fit between indicators and their assessment dimensions and descriptors. 2) required a procedure using performance asesemen practical, efficient and easy to understand in implementing asesemen. Further in the development of much-needed performance asesemen depth study on how to develop procedures asesemen practical and efficient performance.
\end{abstract}

Keywords: develope, assessment instruments, the practice of clothing 


\section{PENDAHULUAN}

Bukti hasil belajar mahasiswa tata busana dapat dinilai melalui proses dan hasil belajarnya. Bukti tersebut dapat berupa berrbagai hal yang diperoleh dalam proses maupun produk busana yang dihasilkan. Untuk menghasilkan produk yang baik, layak, dan sesuai standar, proses dan hasil karya mahasiswa semestinya dapat diarahkan atau diorientasikan pada perkembangan mode yang sesuai selera pasar. Hal ini sesuai dengan konsep dari pembelajaran berbasis produksi.

Untuk dapat menghasilkan suatu produk busana yang sesuai dengan trend dan selera pasar membutuhkan kemampuan dasar tentang analisis mode, dan bagaimana mengaplikasikan mode itu sehingga menjadi karya yang baik. Kurangnya sumber belajar dan kurangnya

kemampuan mengembangkan dan memanfaatkan sumber belajar sangat berdampak pada sulitnya mengarahkan dan menanamkan konsep berkarya yang sesuai dengan perkembangan trend.

Dilihat dari hal di atas dan dengan mempertimbangkan kompleksitas pengetahuan dan keterampilan yang perlu dikuasai oleh mahasiswa dan hasil yang diharapkan tampak sangat dibutuhkan upaya nyata dalam mengelola pembelajaran maupun dalam proses asessemennya.

Guna menuju ke arah itu telah dikembangkan model pembelajaran yang diarahkan pada pembelajaran berbasis produksi melalui pemanfaatan dan pengembangan sumber belajar. Sehingga sangat diperlukan pengembangan asessemen yang autentik dan sesuai dengan karakteristik mata kuliah. Dengan ungkapan lain yaitu penilaian keberhasilan pada peserta didik harus pada penilaian sebenarnya atau difokuskan pada kemampuan melakukan suatu pekerjaan yang dapat dilihat dari ketuntasan hasil belajar mahasiswa melalui asesmen proses dan hasil belajar melalui buktibukti hasil belajar (learning eviden).

Mata kuliah praktek tata busana (praktek membuat busana) memerlukan kreatifitas, keterampilan, dan kinerja yang tinggi. Mata kuliah praktek ini merupakan penerapan kemampuan dasar teori maupun kemampuan dasar praktek yang telah diperoleh sebelumnya. Disamping penerapan konsep dan prinsip desain, mata kuliah ini juga memerlukan kemampuan dasar tentang bagaimana desain tersebut dapat diterapkan atau diproduksi menjadi produk busana yang memiliki daya pakai dan daya seni yang aplikatif sesuai dengan arah dan konsep desain. Karakteristik mata kuliah praktek tata busana dicirikan oleh beberapa aspek kemampuan/ unjuk kerja yang meliputi: merancang dan menganalisa desain, membuat pola dan pecah model, baik pada pola kertas ataupun pola pada bahan, kemampuan memotong bahan sesuai karakteristik bahan, menjahit/menggabungkan bagianbagian busana.

Karakteristik mata kuliah praktek tersebut dicirikan oleh akhir dari proses pembelajaran tersebut harus menunjukkan hasil pembelajaran dalam bentuk kinerja dan produk yang sesungguhnya. Dengan demikian, semestinya hal ini layak menjadi bahan kajian guna mengetahui kinerja mahasiswa dapat dilakukan pengamatan melalui asessmen yang 
bersifat komprehensif, dalam arti asesmen dilakukan terhadap proses dan produk. Bila pada masa lalu fokus pembelajaran adalah pada produk, pada masa sekarang proses dan produk mendapat porsi perhatian yang seimbang. Hal ini didasari oleh asumsi bahwa suatu produk yang baik seyogyanya didahului oleh proses yang baik. Untuk meyakinkan hal tersebut, perlu dilakukan pemantauan terhadap proses. Di samping itu, dengan dilakukannya pemantauan selama proses, terbuka peluang bagi mahasiswa untuk mendapatkan umpan balik yang dapat digunakannya untuk menghasilkan produk terbaik.

Kenyataan menunjukkan bahwa belum ada evaluasi yang baku untuk mengukur keahlian pada mata kuliah praktek pembuatan busana. Untuk memberikan skor cenderung bersifat subyektif, bahkan asesmen tidak dilaksanakan secara bertahap sesuai dengan langkah-langkah yang harus dilakukan untuk menciptakan suatu busana. Semestinya proses yang dilakukan mahasiswa dari awal sampai akhir sudah dievaluasi dengan suatu asesmen yang jelas dan standar.

Konsekuensi yang terjadi dari penilaian yang dilakukan sebelumnya pada mata kuliah praktek tata busana belum sepenuhnya dapat menggambarkan kemampuan yang sebenarnya. Melihat kenyataan seperti itu, nampaknya perlu dikembangkan satu model asessmen yang jelas untuk dapat mengukur kinerja mahasiswa dengan sesungguhnya. Sehingga dengan demikian penelitian ini difokuskan pada pengembangan instrument asesmen mata kuliah praktek pembuatan busana pada Program Studi Pendidikan Tata Busana.

Asesmen otentik menuntut mahasiswa menunjukkan kinerja, bukan menjawab atau memilih jawaban dari sederetan kemungkinan jawaban yang telah disediakan. Asesmen otentik perlu digunakan dalam pembelajaran agar mahasiswa dapat menunjukkan kemampuannya secara langsung terhadap proses dan hasil belajar.

Asesmen otentik dapat memperbaiki proses pembelajaran, karena asesmen dapat membantu para dosen dalam membuat keputusankeputusan selama proses pembelajaran (Fuchs, 1995). Setidaknya ada tiga keputusan yang harus dibuat dosen, yaitu penempatan, formatif, dan diagnostik. Ketiga bentuk keputusan tersebut sangat membantu proses pembelajaran, sehingga mencapai tujuan yang telah ditetapkan.

Orientasi penelitian ini adalah pengembangan instrument asesmen otentik. Dipilihnya asesmen otentik, karena mata kuliah ini berbasis pengetahuan, konsep, dan keterampilan (skill). Keterampilan ini tepatnya diases dengan asesmen yang otentik mulai dari proses mendesain sampai menentukan desain kerja yang diorientasikan pada proses produksi.

Penelitian ini merupakan penelitian pengembangan yang menghasilkan perangkat instrumen asesmen yang dapat dipakai sebagai acuan dalam mengevaluasi proses dan hasil belajar untuk mata kuliah praktek membuat busana.

Alur penelitian yang dilakukan dengan model rancangan yang diadopsi dari model rancangan Dick and Carey. Model ini merupakan seperangkat 
prosedur yang berurutan untuk mewujudkan suatu proses melaksanakan pengembangan sistem dan alat penilaian. Model ini terdiri dari beberapa bagian/ tahapan yang saling berhubungan, satu bagian/ tahapan sebelumnya memperlihatkan balikan dari tahapan sebelumnya. Setiap tahapan mengacu ke perangkat prosedur dan teknik yang dipakai untuk merancang, memproduksi, memvalidasi, dan mengubah/memperbaiki instrumen. Masalah pokok penelitian ini adalah 1) bagaimana mengembangkan perangkat asesmen sebagai asesmen proses dan produk mata kuliah praktek tata busana pada Progran Studi Pendidikan Tata Busana, 2) bagaimana prosedur penggunaan perangkat instrumen asesmen Mata Kuliah Praktek Tata Busana di Program Studi Pendidikan Tata Busana?

Tujuan penelitian ini adalah mengembangkan perangkat instrumen asesmen otentik sebagai asesmen proses dan produk untuk Mata Kuliah Desain Busana. Secara rinci tujuan penelitian dapat dirumuskan sebagai berikut. 1) Merancang instrumen asesmen kinerja mata kuliah praktek tata busana di Program Studi Pendidikan Tata Busana. 2) mengetahui prosedur penggunaan perangkat instrumen asesmen Mata Kuliah Praktek Tata Busana di Program Studi Pendidikan Tata Busana?

\section{METODE PENELITIAN}

Penelitian ini bertujuan untuk mengembangkan perangkat instrumen asesmen sebagai asesmen proses dan produk dalam mata kuliah praktek tata busana di Program Studi Pendidikan Tata Busana. Penelitian ini merupakan penelitian pengembangan (research and development) dengan beberapa tahapan. Subjek penelitian ini adalah mahasiswa Program Studi Pendidikan Tata Busana, dengan fokus penelitian adalah Pengembangan Asesmen Otentik.

Adapun aspek-aspek penelitian, sumber data, teknik dan instrumen/alat pengumpul data, dan validasi dan reliabilitas instrumen yang digunakan dalam penelitian dilakukan dengan teknik wawancara, observasi, dan pencatatan dokumen.

Data penelitian ini berupa data kuantitatif, dan analisis dilakukan dengan analisis statistik. Analisis deskriptif juga dilakukan untuk memberi makna terhadap deskripsi data yang berkaitan dengan keseluruhan tahapan penelitian. Analisis statistik digunakan terkait dengan formula-formula uji empirik (validasi instrumen) yang meliputi uji content validity Analisis statistik digunakan terkait dengan formula-formula uji empirik (validasi instrumen) yang meliputi uji content validity dengan analisis faktor. Indek reliabilitas dihitung dengan koefisien alpha dari Cronbach dan kriteria instrumen yang reliabel ditunjukkan oleh koefisien reliabilitas

\section{HASIL PENELITIAN}

Rancangan perangkat instrumen asesemen dikembangkan melalui tahap analisis kebutuhan instrumen yang dilakukan melalui kajian pustaka dan kajian terhadap kompetensi mata kuliah praktek tata busana dengan melibatkan tim peneliti dan pengampu mata kuliah, kajian ini menghasilkan beberapa aspek penting yang perlu diungkap dalam penilaian praktek tata 
busana yang diturunkan dari beberapa standar kompetensi dan kompetensi dasar, serta indikator pencapaian hasil belajar yang dikehendaki dalam Mata Kuliah Praktek Tata Busana, dengan mengurutkan kemampuan-kemampuan berdasarkan urutan pengamatan. Adapun beberapa aspek kemampuan/ unjuk kerja tersebut diuraikan menjadi beberapa tahapan yaitu : 1) unjuk kerja menganalisa desain, 2) unjuk kerja membuat pola dan pecah model, 3) unjuk kerja penempatan pola pada bahan dan memotong bahan, 4) unjuk kerja menjahit/menggabungkan bagianbagian busana.

Dari unjuk kerja yang diamati sebagai kinerja praktek mahasiswa tersebut, selanjutnya dirancang kisi-kisi instrumen penilaian kinerja, dan selanjutnya dikembangkan rubric penilaian kinerja dan pedoman penskorannya dengan model rating scale.

Disamping pengembangan
penilaian kinerja di atas, juga dikembangkan instrumen penilaian hasil kerja atau produk yang merupakan perangkat asesemen penilaian yang dilakukan untuk mengontrol proses dan pemanfaatan atau penggunaan bahan untuk menghasilkan sesuatu, kerja praktek atau kualitas estetik dari sesuatu yang diproduksi. Dalam hal ini adalah produksi busana sesuai dengan desain/gambar yang ditentukan. Pengembangan instrumen penilaian produk ini diawali dengan tugas yang harus diselesaikan mahasiswa dalam membuat produk busana mulai dari merancang sampai menghasilkan produk. Berikut ini diuraikan rancangan penilaian produk pembuatan busana. Pengembangan perangkat asesmen.
Pengembangan perangkat ini meliputi validasi konten rancangan instrumen asesmen dengan uji judges(expert validity), revisi intrumen asesmen berdasarkan uji pakar, validasi dan reliabilitas secara empirik instrumen asesmen melalui implementasi dalam Mata Kuliah Praktek Busana oleh mahasiswa yang telah mengambil Mata Kuliah praktek Busana.

Validitas instrumen dilakukan terhadap validitas isi dan validitas konstruk. Validitas isi dimaksudkan untuk mengetahui sejauhmana instrumen mencerminkan isi yang dikehendaki. Validitas konstruk mengarah pada sejauhmana instrumen mengukur sifat bangunan pengertian atau konstruk tertentu. Validitas isi terhadap instrumen dalam penelitian ini dilakukan dengan mengkonsultasikan dengan beberapa ahli (experts judgment). Melalui experts judgment ini dapat diketahui apakah setiap butir instrumen telah menggambarkan indikator dari setiap variabel secara teori atau belum, selanjutnya diperoleh instrumen yang dapat memenuhi dan mencerminkan keseluruhan isi yang hendak diukur.

Instrumen asesmen yang dikembangkan menjadi kisi-kisi instrumen dan draft instrumen asesmen pada tahap ini dikonsultasikan kepada ahli (expert) yang terdiri dari ahli evaluasi 1 orang, ahli konten 1 orang, dan praktisi di bidang tata busana 1 orang, pemanfaatan expert dalam hal ini adalah sebagai satu langkah validitas yaitu validitas isi intrumen. Melalui judgment experts ini dapat diketahui apakah setiap butir instrumen telah menggambarkan indikator dari setiap variabel secara teori atau belum, 
selanjutnya diperoleh instrumen yang dapat memenuhi dan mencerminkan keseluruhan isi yang hendak diukur.

Selanjutnya untuk mengetahui validitas konstruk dilakukan dengan analisis faktor. Pertama instrumen diujicobakan pada sampel (mahasiswa Program studi Tata Busana yang berjumlah 17 orang), kemudian dilakukan analisis faktor, yaitu dengan mengkorelasikan antar skor item tiap instrumen, dalam instrumen penelitian ini analisis faktor menggunakan bantuan analisis SPSS 17.0 for Windows. Sedangkan pedoman dalam memberikan interpretasi terhadap koefisien korelasi dalam analisis item. Item/butir instrumen mempunyai korelasi positif dengan kriterium (skor total) dan korelasi yang tinggi, menunjukkan bahwa item tersebut mempunyai validitas yang tinggi pula. Syarat minimum yang dapat dianggap memenuhi syarat adalah $r=0,30$, jika korelasi antar butir instrumen dengan skor total kurang dari 0,30 maka butir tersebut tidak valid dan menunjukkan adanya korelasi yang lemah, dan selanjutnya butir itu digugurkan. Hasil uji coba menunjukkan : dari 5 faktor dan 40 butir instrumen yang diuji coba pada 17 responden, yang selanjutnya dianalisis dengan SPSS 17.0 for windows dengan analisis faktor, tidak terdapat butir yang memiliki muatan faktor kurang dari 0,3 semua butir memiliki muatan factor (cronbach's alpha) di atas 0.5. Hal ini berarti semua butir dari instrumen asesmen memiliki syarat validitas.

Reliabilitas instrumen asesmen Praktek Tata Busana dianalisis dengan menggunakan formula Cronbach diperoleh: 1) koefisien reliabilitas gabungan untuk intrumen unjuk kerja menganalisa desain sebesar 0.843. 2) koefisien reliabilitas gabungan untuk intrumen unjuk kerja membuat pola dan pecah model sebesar 0.826. 3) koefisien reliabilitas gabungan untuk intrumen unjuk kerja penempatan pola pada bahan dan memotong bahan sebesar 0.629. 4) koefisien reliabilitas gabungan untuk intrumen unjuk kerja menjahit/menggabungkan bagianbagian busana sebesar 0.840 , dan 5) koefisien reliabilitas gabungan untuk intrumen penilaian produk busana sebesar 0.893. Semua koefisien ini lebih besar dari 0,5 yang merupakan syarat minimum. Hal ini berarti instrumen tersebut yang dikembangkan mempunyai reliabilitas yang memadai dan layak digunakan untuk melakukan pengukuran.

Penyempurnaan perangkat asesmen meliputi: analisis hasil uji coba dan perbaikan (revisi berdasarkan hasil uji coba empirik) instrumen asesmen. Instrumen asesmen yang telah dianalis selanjutnya di perbaiki dan disempurnakan dari segi format penulisan, penggunaan bahasa, dan pengurangan butir-butir yang gugur pada saat analisis validitas dan reliabilitas, serta menyusun kembali sehingga merupakan kesatuan yang utuh.

2) Prosedur Penggunaan Perangkat Instrumen Asesmen Mata Kuliah Praktek Tata Busana

Pembelajaran yang praktek semestinya dapat diarahkan untuk mengembangkan kemampuan memecahkan masalah-masalah yang berkaitan dengan pengembangan busana dengan berbagai bentuk dan desain. Disamping itu dapat juga dikembangkan kemampuan dalam hal 
wawasan berpikir pada permasalahan atau kemungkinan perkembangan busana di masa yang akan datang. Hal ini mungkin disebabkan oleh penggunan asesmen yang kurang tepat. Asesmen dan pembelajaran merupakan satu kesatuan yang utuh dalam pengembangan aspek pembelajaran. Oleh karena itu pengembangan asesmen sangat membutuhkan perhatian yang serius seperti halnya dalam pengembangan pembelajaran.

Pembelajaran praktek di

Program studi Pendidikan Tata Busana menunjukkan bahwa tidak ditemukan penggunaan asesmen kinerja dalam penilaian praktek. Hanya beberapa yang menyebutkan pernah menggunakan asesmen kinerja, akan tetapi penggunaannya kurang praktis dan membutuhkan waktu dan perhatian yang sangat banyak. Sebagian menyebutkan asesemen yang digunakan lebih berorientasi pada penggunaan asesemen yang berbentuk penilaian produk dan sangat mengabaikan proses yang dilalui. Padahal dalam proses praktek tata busana terdapat sejumlah nilai, sikap, dan keterampilan yang perlu mendapat perhatian untuk dikembangkan yang pada akhirnya akan berkontribusi pada hasil praktikum. Sebagian dari mereka yang diwawancara mengatakan tidak memiliki pemahaman yang jelas tentang cara melaksanakan asesmen kinerja.

Tingginya beban kerja dosen dalam mengajar praktek di Program studi Pendidikan Tata Busana sangat berpengaruh terhadap kebutuhkan suatu prosedur penggunaan asesemen kinerja yang bersifat praktis, efisien dan mudah dipahami. Belum lagi dibutuhkan waktu yang cukup lama untuk melakukan asesemen. Sehingga untuk lebih lanjut dalam pengembangan asesemen kinerja sangat dibutuhkan kajian yang mendalam tentang bagai mana mengembangkan prosedur asesemen kinerja yang praktis dan efisien.

\section{PEMBAHASAN}

Dari beberapa langkah penyusunan dan pengembangan perangkat instrumen asesmen Praktek Tata Busana yang dilaksanakan, diperoleh seperangkat asesmen penilaian yang terdiri dari 40 butir tes yang telah memiliki validitas dan reliabilitas yang dapat diandalkan.

Pada tahap pertama dilaksanakan studi kepustakaan dan kajian empirik dengan maksud agar dalam penyusunan butir tes memiliki struktur dan landasan pengukuran yang kuat dan sesuai dengan kebutuhan pengukuran. Selanjutnya dikembangkan kisi-kisi instrumen dan penyusunan draft perangkat asesmen. Draft perangkat asesmen ini dikonsultasikan dengan ahli atau expert dalam bidang evaluasi, dalam bidang tata busana, dan dengan praktisi tata busana. Selanjutnya dilakukan uji coba dengan maksud agar instrumen tes yang disusun memiliki validitas dan reliabilitas tes yang dapat diandalkan sesuai dengan maksud penggunaan instrumen.

Validitas instrumen dilakukan terhadap validitas isi dan validitas konstruk. Validitas isi dimaksudkan untuk mengetahui sejauhmana instrumen mencerminkan isi yang dikehendaki. Validitas konstruk mengarah pada sejauhmana instrumen mengukur sifat bangunan pengertian 
atau konstruk tertentu (Furchan, 1982). Validitas isi terhadap perangkat instrumen dalam hal ini dilakukan dengan mengkonsultasikan dengan para ahli dan pembimbing (judgment experts). Melalui judgment experts ini dapat diketahui apakah setiap butir instrumen telah menggambarkan indikator dari setiap variabel secara teori atau belum, selanjutnya diperoleh instrumen yang dapat memenuhi dan mencerminkan keseluruhan isi yang hendak diukur.

Selanjutnya untuk mengetahui validitas konstruk dilakukan dengan analisis faktor. Pertama instrumen diujicobakan pada sampel dari mana populasi diambil, kemudian dilakukan analisis faktor, yaitu dengan mengkorelasikan antar skor item tiap instrumen. Sedangkan pedoman dalam memberikan interpretasi terhadap koefisien korelasi dalam analisis item, Masrun (1979) menyatakan item mempunyai korelasi positif dengan kriterium (skor total) dan korelasi yang tinggi, menunjukkan bahwa item tersebut mempunyai validitas yang tinggi pula. Biasanya syarat minimum yang dapat dianggap memenuhi syarat adalah $r=0,30$, jika korelasi antar butir instrumen dengan skor total kurang dari 0,30 maka butir tersebut tidak valid dan menunjukkan adanya korelasi yang lemah, dan selanjutnya butir itu digugurkan.

Sedangkan penghitungan reliabilitas instrumen menggunakan kaidah Cronbach alpha, dengan mencari koefisien reliabilitas gabungan. Menurut Thorndike dan Hagen (Fernades, 1984), bila instrumen menggunakan skala likert, indek reliabilitasnya dapat dihitung dengan koefisien alpha dari Cronbach dan kriteria instrumen yang reliabel ditunjukkan oleh koefisien reliabilitas lebih atau sekurang-kurangnya 0,5.

Langkah terakhir dilakukan penyempurnaan perangkat instrumen. Dalam penyempurnaan ini dilakukan penyempurnaan terhadap penggunaan bahasa dan kalimat yang sesuai dengan kaidah dan penghilangan butir tes yang dianggap tidak valid.

Lebih lanjut dalam pengembangan instrumen asesmen kinerja dibutuhkan prosedur penggunaan asesemen kinerja yang lebih praktis, dan lebih sederhana. Hasil penelitian Wulan (2007) tentang konsep dan prosedur asesmen kinerja yang berlaku selama ini disebutkan terlalu rumit. Sehingga perlu dilakukan penyederhanaan dalam prosedur penggunaan asesemen. Lebih lanjut disebutkan dalam reformasi asesmen kinerja di Indonesia perlu dilakukan penyederhanaan konsep, prinsip dan prosedur asesmen, dan penelitian asesmen di masa datang perlu mengacu pada konsep asesmen yang lebih simple.

\section{SIMPULAN}

Berdasarkan hasil penelitian dan pembahasan yang telah dilakukan, diperoleh simpulan sebagai berikut. 1) Rancangan perangkat instrumen Mata Kuliah Praktek Tata Busana dikembangkan melalui tahap analisis kebutuhan instrumen yang dilakukan melalui kajian pustaka dan kajian terhadap kompetensi mata kuliah dengan melibatkan tim peneliti dan pengampu mata kuliah, kajian ini menghasilkan kisi-kisi perangkat instrument dan perangkat instrument beserta pedoman penskorannya. 
Perangkat instrument tersebut terdiri dari: langkah validitas asesmen dilakukan melaui tahap: 1) dikonsultasikan kepada ahli (expert) Selanjutnya untuk mengetahui validitas konstruk dilakukan dengan analisis faktor. Sedangkan pedoman dalam memberikan interpretasi terhadap koefisien korelasi dalam analisis item. Item/butir instrumen mempunyai korelasi positif dengan kriterium (skor total) dan korelasi yang tinggi, menunjukkan bahwa item tersebut mempunyai validitas yang tinggi pula. Syarat minimum yang dapat dianggap memenuhi syarat adalah $r=0,30$, jika korelasi antar butir instrumen dengan skor total kurang dari 0,30 maka butir tersebut tidak valid, menunjukkan korelasi yang lemah. Dari 40 butir tes menunjukkan validitas yang dapat di andalkan ( $r$ perhitungan $>0.5$ ). Reliabilitas instrumen menggunakan kaidah Cronbach alpha dengan mencari koefisien reliabilitas gabungan. Indek reliabilitasnya dihitung dengan koefisien alpha dari Cronbach dan kriteria instrumen yang reliabel ditunjukkan oleh koefisien reliabilitas lebih atau sekurangkurangnya 0,5 . Dari hasil perhitungan menunjukkan dari 5 instrumen yang dirancang memiliki tingkat reliable yang dapat diandalkan ( $r$ perhitungan $>0.6$ ). 2) Prosedur Penggunaan Perangkat Instrumen Asesmen Mata Kuliah Praktek Tata Busana masih terlalu rumit sehingga diperlukan konsep penyederhanaan prosedur penggunaan asesemen yang mengarah kepada prosedur yang praktis dan efisien.

\section{SARAN}

Dengan melihat hasil penelitian dan pembahasan, dapat disarankan/ direkomendasikan beberapa hal sebagai berikut. 1) Dalam pengembangan instrumen penilaian suatu mata kuliah dapat diempuh langkah-langkah yang telah peneliti lakukan dan perlu melibatkan berbagai pihak seperti ahli evaluasi, ahli konten/ bidang studi maupun praktisi, selanjutnya dilakukan uji validitas dan reliabilitas. 2) Asesemen yang dikembangkan harus disusun secara komprehensip baik dari segi isi/ materi asesemen yang dapat mewakili semua kompetensi dasar maupun indikator yang harus diukur maupun dari bentuk asesemen dan jenis tagihannya. 3) Di tahun berikutnya penelitian ini agar dapat dilanjutkan untuk mengembangkan prosedur asesemen yang lebih sederhana dan lebih praktis tanpa mengurangi makana dan maksud penggunaan asesemen.

\section{DAFTAR PUSTAKA}

Adnyana. P.B. 2005. Penilaian dalam Kurikulum Berbasis Kompetensi. Makalah Disajikan dalam Penataran Guru-guru SMP dan SMA Se-Kabupaten Jembrana. Tidak dipublikasikan

Depdiknas. 2004. Kerangka Dasar Sistem Penilaian Hasil Belajar Peserta Didik SMK. Direktorat Pendidikan Menengah Kejuruan. Depdiknas

Endang Dharmayekti. (1983) Evaluasi Pendidikan Kesejahteraan Keluarga. Jakarta: Departemen Pendidikan dan Kebudayaan.

Fuchs, L.S. (1995). Connecting performance assessment to instruction: A comparison of behavioral assessment, mastery

Jurnal Pendidikan Indonesia | 335 
learning, curriculum-based measurement and performance assessment. ERIC Digest E530.

Hemy Ekayani, I A Pt.2005. Optimalisasi Asesmen Performan untuk Meningkatkan Standar Mutu Layanan dalam Perkuliahan Tata Hidang Mahasiswa Diploma-3 Jurusan Boga Prerhotelan, Artikel, Jurnal Pendidikan dan Pengajaran. IKIP Negeri Singaraja.

Jurnal Pendidikan dan Pengajaran IKIPN Singaraja ISSN 0215-8250 Volume 39 No.2 April 2006 Artikel. Partisipasi Dunia Usaha dan Dunia Industri Dalam Pendidikan Kejuruan Studi Pada Pelaksanaan Praktik Industri Siswa SMK Negeri Di Provinsi Bali Bidang Keahlian Tata Busana. IKIP N Singaraja 2006

Jurnal Pendidikan dan Pengajaran Universitas Pendidikan Ganesha ISSN 0215-8250 Volume 40 No.1 Januari $2007 . \quad$ Artikel. Implementasi Pembelajaran Berbasis Produksi melalui Media dan Sumber Belajar Kontekstual dalam Meningkatkan Kualitas Hasil Belajar Desain Busana Mahasiswa Pendidikan Tata Busana FPTK IKIP Negeri Singaraja. Undiksha, 2007

Pusat Penilaian Pendidikan (2003). Pedoman bagi guru-guru. Jakarta.Balitbang. Depdiknas.

Supri Wiganda,2008, Tuntutan Perkembangan Pendidikan Kejuruan, artikel, Jurnal IImiah Aptekindo

Santyasa, I Wayan . (2004). Buku Ajar: Pengantar Asesmen dan Portofolio. Jurusan Pendidikan Fisika, Fakultas Pendidikan MIPA, IKIP Songaraja.

Sudirtha, I Gede dan Agus Mayuni (2007) Implementasi Pembelajaran berbasis produksi melalui media dan sumber belajar kontekstual pada mahasiswa Program Studi Pendidikan Tata Busana FPTK IKIP Negeri Singaraja. Laporan Penelitian. IKIP Negeri Singaraja. 